\title{
A PDCA-based approach to Environmental Value Stream Mapping (E-VSM)
}

\author{
Jose Arturo Garza-Reyes* \\ Centre for Supply Chain Improvement \\ The University of Derby \\ Kedleston Road Campus, Derby, UK, DE22 1GB \\ E-mail: J.Reyes@ derby.ac.uk \\ Tel. +44(0)1332593281 \\ Joseth Torres Romero \\ Warwick Manufacturing Group, The University of Warwick \\ International Manufacturing Centre, University of Warwick \\ Coventry, UK, CV4 7AL \\ E-mail: J.Torres-Romero@warwick.ac.uk ; torresjoseth@gmail.com
}

\section{Kannan Govindan}

Center for Sustainable Engineering Operations Management

Department of Technology and Innovation

University of Southern Denmark

Odense, Denmark

E-mail:kgov@iti.sdu.dk

Anass Cherrafi

Cadi Ayyad University

Av. Abdelkrim Khattabi, B.P. 511 - 40000

Marrakech - Safi, Morocco

E-mail: a.cherrafi@gmail.com

Usha Ramanathan

Nottingham Business School,

Nottingham Trent University

Burton Street, Nottingham, NG1 4BU, UK

E-mail: usha.ramanathan@ntu.ac.uk

*Corresponding author 


\title{
A PDCA-based approach to Environmental Value Stream Mapping (E-VSM)
}

\begin{abstract}
Research into the application of Value Stream Mapping (VSM) as a tool to enhance the environmental sustainability performance of operations has been confined to a handful of studies only. Research on this green lean research stream is therefore limited, especially when compared to the vast amount of scholarly research focused on the 'traditional' VSM tool. To complement and support the narrow body of knowledge on the application of VSM as tools to improve environmental performance and enhance the effectiveness of its application, this paper proposes an approach, based on the Deming's PDCA improvement cycle, to systematically implement and conduct Environmental-VSM (E-VSM) studies. The implementation of the proposed method is reported through an action research-based case study conducted in a helical rolling process of one of the mining consumables business units of an international diversified mining and materials multinational company. The results of the case study indicate that the proposed DMAIC-based approach to E-VSM can be an effective alternative to improve the green performance of operations. Besides the proposal of this approach, its testing, and expanding the body of knowledge in the green lean field, the paper also contributes by providing a guiding reference for operations managers who may wish to undertake similar improvement projects. Finally, this paper also intends to contribute by inspiring researchers and practitioners to broaden the study of the under-researched field which explores the application of VSM for environmental sustainability enhancement.
\end{abstract}

Keywords: Environmental Value Stream Mapping; Green Lean; Green wastes; Values Stream Mapping, VSM.

\section{Introduction}

Since its developed by Toyota in the 1940-50s, lean has emerged as one of the most dominant managerial paradigms (Forrester et al. 2010) in business environments as extensive theoretical and empirical evidence has demonstrated its effectiveness to enhance the competitiveness of organisations (Belekoukias et al., 2014; Hines et al., 2004). To achieve this, lean focuses on the fierce reduction of non-value added activities, i.e. waste, and relies on an extensive set of tools and techniques. Among the plethora of tools that lean incorporates, Value Stream Mapping (VSM) is considered one of the most essential (Belekoukias et al., 2014), with Womack (2006) considering it "the most important tool lean thinkers will need to make sustainable progress in the war against muda". VSM is a simple and visual process-based tool which enables the documentation, visualisation and comprehension of material and information flows in processes, in order to identify wastes and assist in their elimination (Nash and Poling, 2011). Over the last years, the application of VSM has not only increased within 
manufacturing plants and supply chains (Forno et al., 2014; Abdulmalek and Rajgopal, 2007) but also in process industries and the service sector (Jeyaraj et al., 2013).

Underpinned by the use of VSM, and other tools and techniques, lean has contributed to the attainment of historical and contemporary organisational objectives that include profitability, efficiency, customer satisfaction, quality and responsiveness (Garza-Reyes, 2015a). However, in order to respond to and address the sustainability challenges that organisations are currently facing, the contribution of lean to enhance environmental performance and its integration with the green paradigm and initiatives have recently emerged as a contemporary research stream (e.g. Cherrafi et al., 2017a; Cherrafi et al., 2017b; Garza-Reyes, 2015a; Chiarini, 2014; Dües et al., 2013; etc.). In this context, the academic literature indicates that the relationship between lean and green has been studied in relation to (1) their synergies and divergences (e.g. GarzaReyes, 2015b; Garza-Reyes et al., 2014; Dües et al., 2013), (2) the potential benefits of their integration in different contexts (Garza-Reyes et al., 2016a; Franchetti et al., 2009), (3) their impact on organisational performance, and (4) their theoretical integration (Cherrafi et al., 2017a; Bergmiller and McCright 2009).

To enable the synergies and integration of lean and green, a number of frameworks have been proposed and some of the lean tools adapted to assist improvements in environmental performance. For example, Chefarri et al. (2017a) developed a framework that methodically guides companies to integrate and implement green, lean and six sigma to improve their sustainability performance. Tomelero et al. (2017) proposed a lean environmental benchmarking method for performing a diagnosis of practices and performances to support the implementation of a cutting tool management strategy. Pampanelli et al. (2014) presented an integrated lean and green approach that resulted in the reduction of production waste and environmental impact.

On the other hand, in terms of the adaptation of lean tools to support environmental objectives, due to its increasing popularity, effectiveness and relative simplicity, it is unsurprising to realise that some authors have considered VSM to support the improvement of environmental and sustainability performance. For instance, Wills (2009) extended the concept of value stream, looking at it from the environmental perspective and calling it green value stream, also known as Environmental Value Stream Mapping (E-VSM). Torres and Gati (2009) developed an E-VSM methodology by expanding the U.S. Environmental Protection Agency's (EPA) lean and environmental toolkit. The methodology was validated through a case study conducted in the Brazilian sugar and alcohol manufacturing industry. Taking VSM as a basis, Lai et al. (2008) proposed a framework for combining life-cycle environmental input analysis, total cost analysis, and an energy consumption analysis. Kurdve et al. (2011) used an adaptation of VSM, which they also called E-VSM, at Volvo Penta Vara and Volvo Construction Equipment Braås. Folinas et al. (2014) offered a systematic approach for measuring the environmental performance of a supply chain in the agrifood sector based on VSM. Brown et al. (2014) examined in detail three case studies to demonstrate the breadth of applicability of the Sustainability-VSM tool and the aptness and limitations of the tool in assessing and visualizing sustainability performance in different manufacturing system configurations. Faulkner and Badurdeen (2014) presented a comprehensive methodology to develop Sustainable Value Stream Mapping by identifying suitable metrics and methods to visually present them. Finally, Garza-Reyes et al. (2016a) developed a sustainable version of VSM, called Sustainable Transportation Values Stream Mapping (STVSM), to improve the transport operations of a world leader logistics organisation in the metropolitan area of Monterrey, Mexico. Other studies which have used VSM, and its principles, to drive environmental and/or sustainable improvements include the works of Deif (2011), Kuriger et 
al. (2011), Dadashzadeh and Wharton (2012), Simons and Mason (2002), Fearne and Norton (2009) and Paju et al. (2010).

However, despite the aforementioned studies have successfully demonstrated that by following the VSM methodology it is possible to identify and reduce the negative environmental impact of industrial operations, which leads to reduced costs as well as increased value and competitiveness (Wills, 2009), research into the application of VSM to improve environmental sustainability has been confined to the previously reviewed handful of studies only. Therefore, research on this green lean research stream may still be considered limited, especially when compared to the vast amount of studies focused on the traditional VSM found in the academic literature. To complement and support the narrow body of knowledge on the application of VSM as a tool to enhance environmental sustainability, this paper contributes to the green lean field by proposing a method, based on the Deming's PDCA approach, to systematically conduct an E-VSM study. The implementation of the proposed method is also reported through an action research-based case study conducted in a grinding media manufacturer that aimed at improving the environmental sustainability of its production process, and in this way enhance its overall competitiveness. This paper also contributes by providing a guiding reference for operations managers who may wish to undertake similar improvement projects as well as by expanding the rather limited body of knowledge on environmental VSM. Additionally, this paper also intends to contribute by inspiring researchers and practitioners to broaden the study of this under-researched field. Considering this, the main research questions addressed in this study are:

- Can a popular and relatively simple to use lean tool such as VSM be employed to identify and reduce the negative environmental impact of industrial operations?

- How can the traditional VSM tool be adapted and its approach systematically followed to not only document, visualise and comprehend the flows of 'traditional' material and information in processes but also consider their environmental dimension?

The rest of the paper is organised as follows: Section 2 presents the proposed PDCA-based approach to E-VSM and justifies the action research methodology followed in this study; Section 3 elucidates, through the application of the proposed approach, the steps involved in its implementation to systematically conduct an E-VSM study to identify and eliminate/minimise green wastes present in the value stream of a manufacturing process of the studied organisation. Finally, Section 4, presents the conclusions, limitations and future research directions derived from this paper.

\section{Proposed PDCA-based approach to E-VSM and research methodology}

An E-VSM, like the traditional VSM, should be considered a continuous improvement process where, based on the establishment of a current-state map and after achieving the proposed future-state map, subsequent future-state maps can be drawn to enable a continuous improvement cycle. As suggested by Rother and Shook (2003), VSM involves constant implementation plans for continuous improvement at value-stream level. Thus, and in order to continuously minimise/eliminate waste, Chiarini (2013) and Qassim et al. (2015) aligned the VSM approach with the PDCA cycle.

Based on this rationale, the PDCA-based approach to E-VSM implementation presented in Figure 1 was proposed to provide an effective method to enable the implementation of E-VSM studies in a systematic, repeatable, and continuous cycle of improvement manner. The approach was developed based on three 'design stages'. The first stage entailed studying the features, reason for adapting, and applicability of VSM to improve environmental/sustainable 
performance. This ensured the amalgamation of the most relevant and current theoretical knowledge into the proposed framework (Garza-Reyes et al., 2016b). The second stage consisted in using the theoretical and industrial experience of the authors as consultants, practitioners, academics and researchers to assist the development of the proposed approach as according to Rocha-Lona et al. (2013) these play an important role when creating theoretical frameworks which will be deployed in industry. The theoretical and industrial experience of the authors on green lean is illustrated through a wide range of reported developments and applications of relevant green lean theory and research (e.g. Cherrafi et al., 2017a; Cherrafi et al., 2017b; Garza-Reyes et al., 2016a; Garza-Reyes, 2015a; Garza-Reyes, 2015b; Garza-Reyes et al., 2014; etc.). Lastly, the third stage included the consideration of relevant input from the case company where the approach was applied. Therefore, similarly to the work of GarzaReyes et al. (2016b), discussions with relevant executives, directors, managers and shop-floor staff and initial observations of the company's value stream were also conducted to consider, in the design of the approach, key parameters and issues relevant to E-VSM studies.

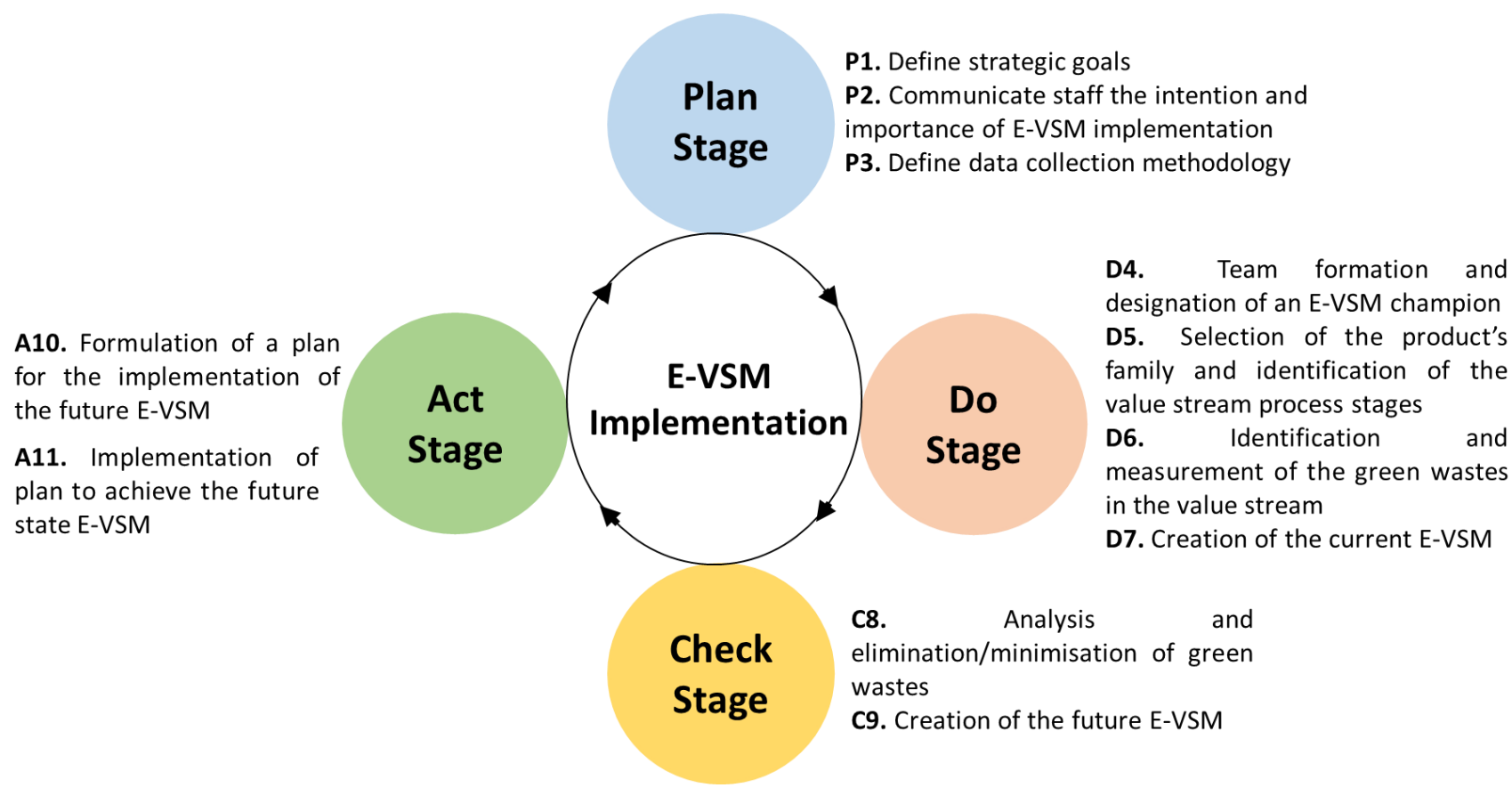

Figure 1. PDCA approach to E-VSM implementation

Once developed, the PDCA approach to E-VSM implementation was applied in one of the mining consumables business units of an international diversified mining and materials multinational company. Specifically, the application focused on a helical rolling process that manufactures grinding ball products, see Figure 2. This characteristic led to an empirical study which most appropriate research methods are action research or case study (Shadish et al., 2002). Since this work required the presence and participation of the researchers to manage, lead, aid and closely track the implementation and management of the proposed PDCA-based approach to E-VSM, action research was considered the most suitable method to carry out this study. This method also helped, through the direct intervention of one of the researchers, in overcoming problems and resistance during the application of the proposed approach (Gutierrez et al. 2015; Coughlan and Coghlan, 2002). In this study, and as advocated by Coughlan and Coghlan (2002), action research evidenced to be an effective method not only to document and report the experiences and lessons learnt by the authors while carrying out the E-VSM study based on the PDCA method proposed but also to test it and draw conclusions 
regarding its effectiveness. For this reason, action research was found to be a valuable research strategy that contributed in advancing the body of knowledge of the green lean field.

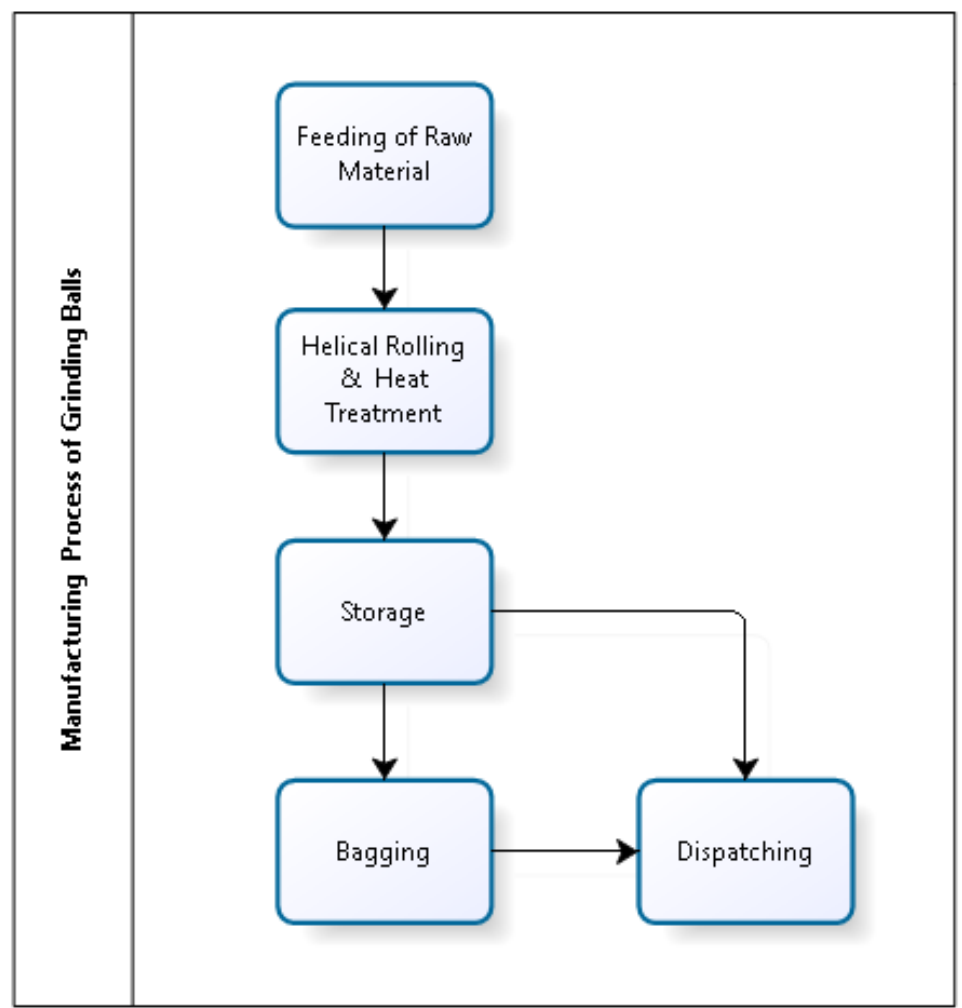

Figure 2. Grinding balls manufacturing process overview

\section{PDCA-based approach to E-VSM definition and application}

\subsection{Plan stage}

\section{P1. Define Strategic Goals}

Clear objectives provide a pathway for organisations to become lean (Chiarini, 2013). Therefore, at the Plan stage, the formulation of goals is important to give the E-VSM implementation a focal point. In this sense, the strategic goal for the E-VSM application in the case organisation was to effectively identify and measure environmental wastes in the value stream of the helical rolling process, see Figure 2, that manufactured grinding balls, to then formulate and undertake suitable strategies to eliminate it in order to move on to the future state.

\section{P2. Communicate the staff the intention and importance of E-VSM implementation}

Following, within the Plan stage it is also important to communicate the staff the goals for implementing the E-VSM. Employee's commitment to the project is essential since their participation and feedback will provide a linkage towards continuous improvement and the creation and achievement of the current and future state maps (Abdulmalek and Rajgopal, 2007). Additionally, environmental practices will only be successfully implemented if these are accompanied by the enhancement of employee's knowledge and competence regarding environmental issues (Cherrafi et al., 2017a). In this case, the intention and importance of EVSM implementation was carried out through a communication campaign that included departmental meetings, staff briefings and training on sustainability and E-VSM. 


\section{P3. Define data collection methodology}

In a VSM study, a rigorous and systematic data collection methodology needs to be defined in order to ferret out sources of waste and to find ways to eliminate them (Qassim et al., 2015). The same applies for the implementation of E-VSM. In the case of this project, the data collection strategy consisted in formulating and following a pre-established data collection plan that included the gathering of data regarding different characteristics of the value stream of the studied helical rolling process. In particular, the data collected included characteristics such as (1) energy and water consumptions; (2) usage rate of the devices/equipment that operated at each process step of the value stream; (3) water toxicity level and its grade of impurity to know the sort of toxins handled in the process and adopting the most suitable cleaning alternative; (4) the grade of recyclability and biodegradability of the materials and substances employed in the process to understand how much they may reuse and how harmful they were; and finally (5) the amount and sources of total emissions generated by the process. The data was gathered through direct observations and measurements of the value stream using some data collection forms created by the authors. To do this, the entire value stream of the studied helical rolling process was followed and observed from end to start (Rother and Shook, 2003) for a period of one month.

\subsection{Do stage}

\section{D4. Team formation and designation of an E-VSM champion}

The next step in the proposed PDCA-based approach to E-VSM consists of forming the team that will carry out the E-VSM implementation and the designation of the champion who will ensure that adequate support is provided to the team and that any barriers that may arise during the E-VSM implementation are removed (Garza-Reyes et al., 2016b). The E-VSM team was formulated with employees who were directly involved in and responsible for various stages of the value stream of the helical rolling process. Furterer (2009) and Garza-Reyes et al. (2016b) suggest that in improvement projects, team members should be selected from those who have adequate knowledge and background on the process. Therefore, the team included the Production Manager responsible for the process, two Team Leaders and one of the authors. The Production Manager was responsible for the full operation of the helical rolling process, whereas the team leaders supported such operations and process. The participant author was the leader of the E-VSM implementation. In addition, the Plant Manager championed the EVSM project. As suggested by Rother and Shook (2003) and Wills (2009), the champion had the authority to make change happen along with providing leadership to the process, also had complete knowledge of lean and green practices, and an understanding of the product's family and operational processes at the case study organisation.

\section{D5. Selection of the product's family and identification of the value stream process stages}

The case organisation manufactures three different families of grinding media products, namely: grinding balls, grinding rods, and mining chemicals for mineral treatment. Each product's family manufacturing process is completely different from the other in terms of equipment and processes employed. As commented by Womack (2006) and Rother and Shook (2003), it is necessary to select a product family before starting a VSM study. Thus, after having formed the team and designated the champion, the next step in the proposed DMAIC-based approach to E-VSM is to select the product family.

For this study, the grinding ball product was selected. Grinding balls are manufactured from steel bars in different sizes and for different applications, e.g. ball mills or SAG mills. Grinding balls are employed in mineral processing ball milling operations, varying in size from 1.0 inch to 4.0 inches in diameter. They are manufactured from high carbon-alloy steel bars. Each diameter of ball has its own chemical composition and heat treatment. SAG balls are designed 
for SAG mill mineral processing operations. Sizes are within a range from 4 inches to 6.25 inches in diameter. In the same manner, each diameter of SAG balls is manufactured with a particular chemical composition from alloy and its corresponding heat treatment.

As suggested by Saboo et al. (2014), the selection of the grinding ball product's family was decided based on the following strategic factors:

a) It was the biggest product family in terms of turnover for the case organisation. This meant that when focusing this study on the main source of materials consumption, energy use, and assets utilisation; a great portion of waste, contamination, and pollution generators would be tackled;

b) The customer had indicated increasing volumes over the following years;

c) The manufacturing process of this specific product involved the use of all major equipment; hence it increased the scope and impact of the E-VSM improvement project.

The value stream of the grinding balls manufacturing process is illustrated in Figure 2. This was identified as indicated in P3.

\section{D6. Identification and measurement of the green wastes in the value stream}

In the proposed approach, the procedure to build the current E-VSM starts with identifying and measuring seven environmental, or green, wastes adapted from the works of Wills (2009), Torres and Gati (2009), Brown et al. (2014) and Faulkner and Badurdeen (2014), i.e. (1) energy, (2) water, (3) materials, (4) garbage, (5) transportation, (6) emissions, and (7) biodiversity. Energy waste appears when consuming more energy than required, which in turn generates a more negative environmental impact when the source of energy are fossil fuels. Water waste emerges when using more water than needed and subsequently having to pay for getting it cleaned. Materials waste is appointed to materials used to build a product which, after accomplished the product life cycle, cannot be reused and end up in the landfill. Garbage waste is when the garbage generated cannot be reused, it generates a negative environmental impact, and companies have to pay to dispose it. Transportation waste comes from unnecessary journeys in the value stream process, which in turn generate a more negative environmental impact when the transportation means burning fossil fuels. Emissions waste is referred to creating and discharging contaminants into the atmosphere. The last green waste is biodiversity, which is related to the destruction of flora, fauna, and organisms; and also consuming natural resources in excess. This waste, however, was considered out of the scope of this project as it requires historical data from the case company regarding the type and amount of biodiversity that existed before the establishment of its facilities/operations, for which data did not exist.

In this case, green wastes were identified and measured sequentially at each process stage of the value stream, see Figure 2. This step prior to the construction of the current state map was undertaken along with the data collection activity, see Section 3.1, P3. All the information and data gathered was noted in waste elimination forms prepared for this purpose. The systematic method followed to identify and measure the six green wastes in the value stream of the helical rolling process is shown in Figure 3. Some examples of the data collected and captured in the waste elimination forms are exemplified in Figure 4. 
Identification and Measurement of Energy Waste

I. Identification of machinery, equipment, or installation whose operation involves the consumption of energy in the form of either electricity or fuel.

II. Gathering of the values of energy either electricity or fuel consumed in each of the identified operations.

III. Measurement of the usage rate for each operation identified.

IV.Calculation of the total energy consumption for each operation during a period of time. This is a simple multiplication of the energies values consumed per the usage rate.

V. Calculation of the cost of using the energy. For this, it is necessary to know the price of energy fixed by the provider.

\section{Identification and Measurement of Materials Waste}

I. Identification of the input materials in the process stage.

II. Assignation of the input material makeup with its chemical composition.

III. Identification of the output materials in the process stage.

IV.Specify whether the input material is made up of recycled or biodegradable materials. If so, note the percentage of recycled or biodegradable material.

V. Specify whether the output materials may be recycled or may be biodegradable after the end of its lifecycle. If so, note the percentage of recyclability or biodegradability.

VI.Classification of the output materials either technical nutrient (recyclable), biological nutrient (biodegradable), or landfill (waste).

VII.Assessment of the environmental and human health impact that represents the output materials.
Identification and Measurement of Water Waste

I. Identification of any equipment or activity in the value stream whose operation consumes water.

II. Determine the flow rate of water per equipment.

III. Determine the usage rate during a period of time.

IV.Calculation of the total consumption of water during a period of time. This is a simple multiplication of the quantity of water consumed per the usage rate.

V. If the system employed retains water, then the difference between the quantity of water consumed and the quantity of water retained would be the water discharged. Otherwise, if the system does not retain water, the quantity of water discharged would be equal to the water consumed. VI.Measure the toxicity of the water discharged.

\section{Identification and Measurement of Garbage Waste}

I. Finding out the garbage bins, cans, or bags situated in the area where each process stage takes place.

II. Identification of the composition of the garbage containers and its material makeup.

III. Measurement of the quantity or weight of garbage items dumped during a time frame.

IV.Classification of the environmental and human health impact that represents the garbage items found. Such classification is done according to the criterion shown in the following figure

\begin{tabular}{|c|l|}
\hline Green & $\begin{array}{l}\text { Little or no risk to the environment or human } \\
\text { health. }\end{array}$ \\
\hline Yellow & $\begin{array}{l}\text { Low or moderate risk. It is acceptable for use } \\
\text { at least it can be substituted with one rated }\end{array}$ \\
\hline Red & $\begin{array}{l}\text { High impact and risk. Phasing out and } \\
\text { replacing it with a green or yellow rated. }\end{array}$ \\
\hline Grey & $\begin{array}{l}\text { Risk data unknown or incomplete. Further } \\
\text { investigation is needed to rate the material. }\end{array}$ \\
\hline
\end{tabular}

\section{Identification and Measurement of Emissions Waste}

I. Find out the sources of emissions and effluents in the value stream.

II.Identification of the type of emissions and effluents coming from each source found out.

III.Measure the amount of emission or effluent during a time frame.

Figure 3. Systematic method to identify and measure the six green wastes (adapted from Wills, 2009) 


\begin{tabular}{|r|c|c|c|}
\hline \multicolumn{3}{|c|}{ Garbage Waste Elimination Worksheet } \\
\hline Product: & \multicolumn{3}{|c|}{ Grinding Balls 2.1/2" } \\
\hline Production Line: & \multicolumn{3}{|c|}{ Helical Rolling 2 } \\
\hline Step: & \multicolumn{3}{|c|}{ Current State } \\
\hline \multicolumn{3}{|c|}{ Measure } \\
\hline Identify & Material & Quantity & Assess \\
\hline Item & Wire rod & $1,441.2 \mathrm{~kg} /$ month & Yellow \\
\hline Wire Rod Box &
\end{tabular}

a) Process stage: Feeding of Raw Material; Green waste: Garbage

\begin{tabular}{|r|c|c|c|}
\hline \multicolumn{2}{|c|}{ Transportation Waste Elimination Worksheet } \\
\hline Product: & \multicolumn{3}{c|}{ Grinding Balls 2.1/2" } \\
\hline Production Line: & \multicolumn{3}{c|}{ Helical Rolling 2 } \\
\hline \multicolumn{2}{|c|}{ 3. Storage } \\
\hline \multicolumn{2}{|c|}{ Current State } \\
\hline Identify & \multicolumn{3}{|c|}{ Measure } \\
\hline Item & Mode & Unit Distance & Total Distance \\
\hline $\begin{array}{c}\text { Grinding Balls } \\
\text { Boxes 6t }\end{array}$ & Bridge Crane & $100 \mathrm{~m} /$ trip & $46,983 \mathrm{~m}$ \\
\hline
\end{tabular}

c) Process stage: Storage; Green waste: Transportation

\begin{tabular}{|c|c|c|c|c|c|c|c|c|}
\hline \multicolumn{9}{|c|}{ Materials Waste Elimination Worksheet } \\
\hline Product: & \multicolumn{8}{|c|}{$\begin{array}{c}\text { Grinding Balls 2.1/2" } \\
\end{array}$} \\
\hline Production Line: & \multicolumn{8}{|c|}{ Helical Rolling 2} \\
\hline Step: & \multicolumn{8}{|c|}{ 4. Bagging } \\
\hline \multicolumn{9}{|c|}{ Current State } \\
\hline Identify & & \multirow{2}{*}{\multicolumn{6}{|c|}{\begin{tabular}{c|}
\multicolumn{2}{c}{ Measure } \\
Material Makeup
\end{tabular}}} & \\
\hline \multicolumn{2}{|l|}{ Input } & & & & & & & \multirow[b]{2}{*}{ Assess } \\
\hline Item \& Qty & $\begin{array}{l}\text { Material } \\
\text { Makeup }\end{array}$ & Item & Input & Output & $\begin{array}{c}\text { Technical } \\
\text { Nutrient } \\
\text { (Recyclable) }\end{array}$ & $\begin{array}{c}\text { Biological } \\
\text { Nutrient } \\
\text { (Biodegradable) }\end{array}$ & Landfill & \\
\hline $\begin{array}{l}\text { Polypropylene Bag } \\
\text { (422 units/month) }\end{array}$ & $\begin{array}{c}100 \% \\
\text { Polypropylene }\end{array}$ & $\begin{array}{c}\text { Polypropylene } \\
\text { Bag }\end{array}$ & $\begin{array}{c}0 \% \\
\text { recycled }\end{array}$ & $\begin{array}{c}100 \% \\
\text { recyclable }\end{array}$ & $\mathrm{x}$ & & & Yellow \\
\hline
\end{tabular}

b) Process stage: Bagging; Green waste: Materials

Figure 4. Evidence of data collected from the six green wastes in some process stages

\begin{tabular}{|c|c|c|c|c|c|}
\hline \multicolumn{6}{|c|}{ Energy Waste Elimination Worksheet } \\
\hline Product: & \multicolumn{5}{|c|}{ Grinding Balls 2.1/2" } \\
\hline Production Line: & \multicolumn{5}{|c|}{ Helical Rolling 2} \\
\hline Step: & \multicolumn{5}{|c|}{ 2. Helical Rolling \& Heat Treatment } \\
\hline \multicolumn{6}{|c|}{ Current State } \\
\hline \multicolumn{2}{|l|}{ Identify } & \multicolumn{4}{|c|}{ Measure } \\
\hline \multirow{2}{*}{ Equipment } & \multirow{2}{*}{ Source } & \multirow{2}{*}{ Rate } & \multirow{2}{*}{ Usage } & \multicolumn{2}{|c|}{ Consumption } \\
\hline & & & & Qty & Cost (USD/kW-h) \\
\hline Electrical Motors for Bars Feeding & Electricity & $2 \mathrm{~kW}$ & $84.3 \mathrm{~h} / \mathrm{month}$ & $168.7 \mathrm{~kW}-\mathrm{h} / \mathrm{month}$ & 8.10 \\
\hline Electrical Motors for Bars Heating $(x 3)$ & Electricity & $6 \mathrm{~kW}$ & $84.3 \mathrm{~h} / \mathrm{month}$ & $506.0 \mathrm{~kW}-\mathrm{h} / \mathrm{month}$ & 24.29 \\
\hline Converters & Electricity & $3100 \mathrm{~kW}$ & $337.3 \mathrm{~h} / \mathrm{month}$ & $1,045,630.0 \mathrm{~kW}-\mathrm{h} / \mathrm{month}$ & $50,190.24$ \\
\hline Electrical Motors for Converter Cooling & Electricity & $20 \mathrm{~kW}$ & $337.3 \mathrm{~h} / \mathrm{month}$ & 6,746.0 $\mathrm{kW}-\mathrm{h} / \mathrm{month}$ & 323.81 \\
\hline Electrical Motors for Water Cooling & Electricity & $20 \mathrm{~kW}$ & $337.3 \mathrm{~h} / \mathrm{month}$ & $6,746.0 \mathrm{~kW}$-h/month & 323.81 \\
\hline Fan Motors Cooling Tower 1 (x2) & Electricity & $150 \mathrm{~kW}$ & $112.4 \mathrm{~h} / \mathrm{month}$ & $16,866.5 \mathrm{~kW}-\mathrm{h} / \mathrm{month}$ & 809.59 \\
\hline Electrical Motors for Hydraulic Units & Electricity & $100 \mathrm{~kW}$ & $337.3 \mathrm{~h} / \mathrm{month}$ & $33,730.0 \mid \mathrm{kW}-\mathrm{h} / \mathrm{month}$ & $1,619.04$ \\
\hline Electrical Motors for Hydraulic Units Cooling & Electricity & $30 \mid \mathrm{kW}$ & $337.3 \mathrm{~h} / \mathrm{month}$ & \begin{tabular}{ll|l|}
$10,119.0$ & $\mathrm{~kW}-\mathrm{h} / \mathrm{month}$ \\
\end{tabular} & 485.71 \\
\hline Fan Motors Cooling Tower 2 (x2) & Electricity & $150 \mathrm{~kW}$ & $112.4 \mathrm{~h} / \mathrm{month}$ & $16,865.0 \mathrm{~kW}-\mathrm{h} / \mathrm{month}$ & 809.52 \\
\hline Electrical Motors for Rolls Cooling & Electricity & $10 \mathrm{~kW}$ & $337.3 \mathrm{~h} / \mathrm{month}$ & 3,373.0 kW-h/month & 161.90 \\
\hline Prime Motor & Electricity & $1000 \mathrm{~kW}$ & $337.3 \mathrm{~h} / \mathrm{month}$ & $337,300.0 \mathrm{~kW}-\mathrm{h} / \mathrm{month}$ & $16,190.40$ \\
\hline Electrical Motor for Prime Motor Cooling & Electricity & $15 \mathrm{~kW}$ & $337.3 \mathrm{~h} / \mathrm{month}$ & \begin{tabular}{|l|l|}
$5,059.5$ & $\mathrm{~kW}-\mathrm{h} /$ month \\
\end{tabular} & 242.86 \\
\hline Electrical Motor for Gearbox Cooling & Electricity & $3.5 \mathrm{~kW}$ & $337.3 \mathrm{~h} / \mathrm{month}$ & $1,180.6 \mathrm{~kW}-\mathrm{h} / \mathrm{month}$ & 56.67 \\
\hline Electrical Motor for Cooling Table & Electricity & $2.2 \mathrm{~kW}$ & $337.3 \mathrm{~h} / \mathrm{month}$ & $742.1 \mathrm{~kW}-\mathrm{h} /$ month & 35.62 \\
\hline Electrical Motor for Quenching Drum & Electricity & $20 \mathrm{~kW}$ & $337.3 \mathrm{~h} / \mathrm{month}$ & 6,746.0 kW-h/month & 323.81 \\
\hline Electrical Motor for Quenching Water & Electricity & $20 \mathrm{~kW}$ & $337.3 \mathrm{~h} / \mathrm{month}$ & $6,746.0 \mathrm{~kW}$-h/month & 323.81 \\
\hline Fan Motors Cooling Tower 4 (x2) & Electricity & $150 \mathrm{~kW}$ & $112.4 \mathrm{~h} / \mathrm{month}$ & $16,865.0$ kW-h/month & 809.52 \\
\hline Drive & Electricity & $1000 \mathrm{~kW}$ & $337.3 \mathrm{~h} / \mathrm{month}$ & \begin{tabular}{|l|l|}
$337,300.0$ & $\mathrm{~kW}-\mathrm{h} / \mathrm{month}$ \\
\end{tabular} & $16,190.40$ \\
\hline Lighting (x30) & Electricity & \begin{tabular}{l|l}
12 & $\mathrm{~kW}$ \\
\end{tabular} & \begin{tabular}{l|l|}
$337.3 \mathrm{~h} / \mathrm{month}$ \\
\end{tabular} & \begin{tabular}{l|l|}
$4,047.6 \mathrm{~kW}$-h/month \\
\end{tabular} & 194.28 \\
\hline $\mathrm{AC}$ & Electricity & $5 \mathrm{~kW}$ & $337.3 \mathrm{~h} / \mathrm{month}$ & $1,686.5 \mid \mathrm{kW}-\mathrm{h} / \mathrm{month}$ & 80.95 \\
\hline
\end{tabular}

b) Process stage: Helical Rolling and Heat Treatment; Green waste: Energy

\begin{tabular}{|r|c|c|}
\hline \multicolumn{2}{|c|}{ Emissions Waste Elimination Worksheet } \\
\hline Product: & \multicolumn{2}{c|}{ Grinding Balls 2.1/2" } \\
\hline Production Line: & \multicolumn{2}{c|}{ Helical Rolling 2 } \\
\hline \multicolumn{2}{|c|}{ Step: Dispatching } \\
\hline \multicolumn{2}{|c|}{ Current State } \\
\hline Identify & Type & Measure \\
\hline Item & $\mathrm{NOx}$ & $14.6 \mathrm{gr} / \mathrm{month}$ \\
\hline Forklift 3t & $\mathrm{CO}_{2}$ & $51.3 \mathrm{gr} / \mathrm{month}$ \\
\hline Forklift 3t & &
\end{tabular}

e) Process stage: Dispatch; Green waste: Emissions 


\section{D7. Creation of current E-VSM}

After the identification and measurement of the green wastes, the following step in the proposed approach to E-VSM is to create the current state map. For this purpose, the methodology suggested by Rother and Shook (2003) to construct a 'traditional' VSM was adapted to incorporate the green objectives/wastes defined by Wills (2009), Torres and Gati (2009), Brown et al. (2014) and Faulkner and Badurdeen (2014). Thus, a blueprint of the value stream, depicting each process step in data boxes, see Figure 5, with its corresponding values of green wastes previously measured was developed. The blue print also illustrated how the raw material was received and how the finished product was delivered by using a track symbol, as well as the direction of the information flow that supported the helical rolling process. A broken arrow was used to indicate the flow of electronic information and a solid arrow for physical flows. The E-VSM sequence was the same as that shown in Figure 2. The current EVSM is shown in Figure 6.

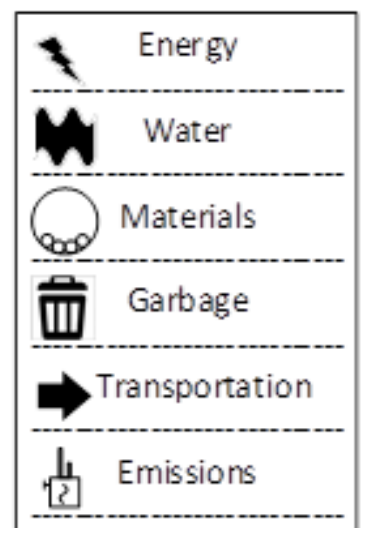

Figure 5. Data boxes used to depict green wastes

\subsection{Check stage}

\section{C8. Analysis and elimination/minimisation of green wastes}

Similarly as the current state map of the 'traditional' VSM, the current state E-VSM map enables the evaluation of process operations, but in this case, in relation to green rather than non-value added/lean wastes (Dickson et al., 2009). Clear identification of waste, either in the form of materials, information flows, or green wastes in the current state map is essential to identify performance improvement opportunities in the future state map (Hamad et al., 2012). This will support the improvement team on the task of formulating and implementing effective strategies for their elimination/reduction. Thus, after creating the current E-VSM, the following step in the proposed approach refers to the analysis, interpretation and proposal of strategies for the elimination/minimisation of the green wastes identified in the value stream of the studied process.

In the case of this study, the analysis process to eliminate/minimise the green wastes identified in the current state E-VSM was constituted by a number of strategies proposed by Wills (2009), along with the selection of appropriate lean tools and techniques that supported such elimination/minimisation. Table 1 presents the green waste elimination strategies formulated for every stage of the helical rolling process, whereas Table 2 indicates the specific activities that were considered as part of the green waste reduction/minimisation strategies followed. Additionally, Figure 7 presents an example of the analyses carried out in order to assess the effectiveness and potential impact of the strategies to address the green wastes. These analyses served as the basis to create the future state E-VSM, see step C9 in the following section. 


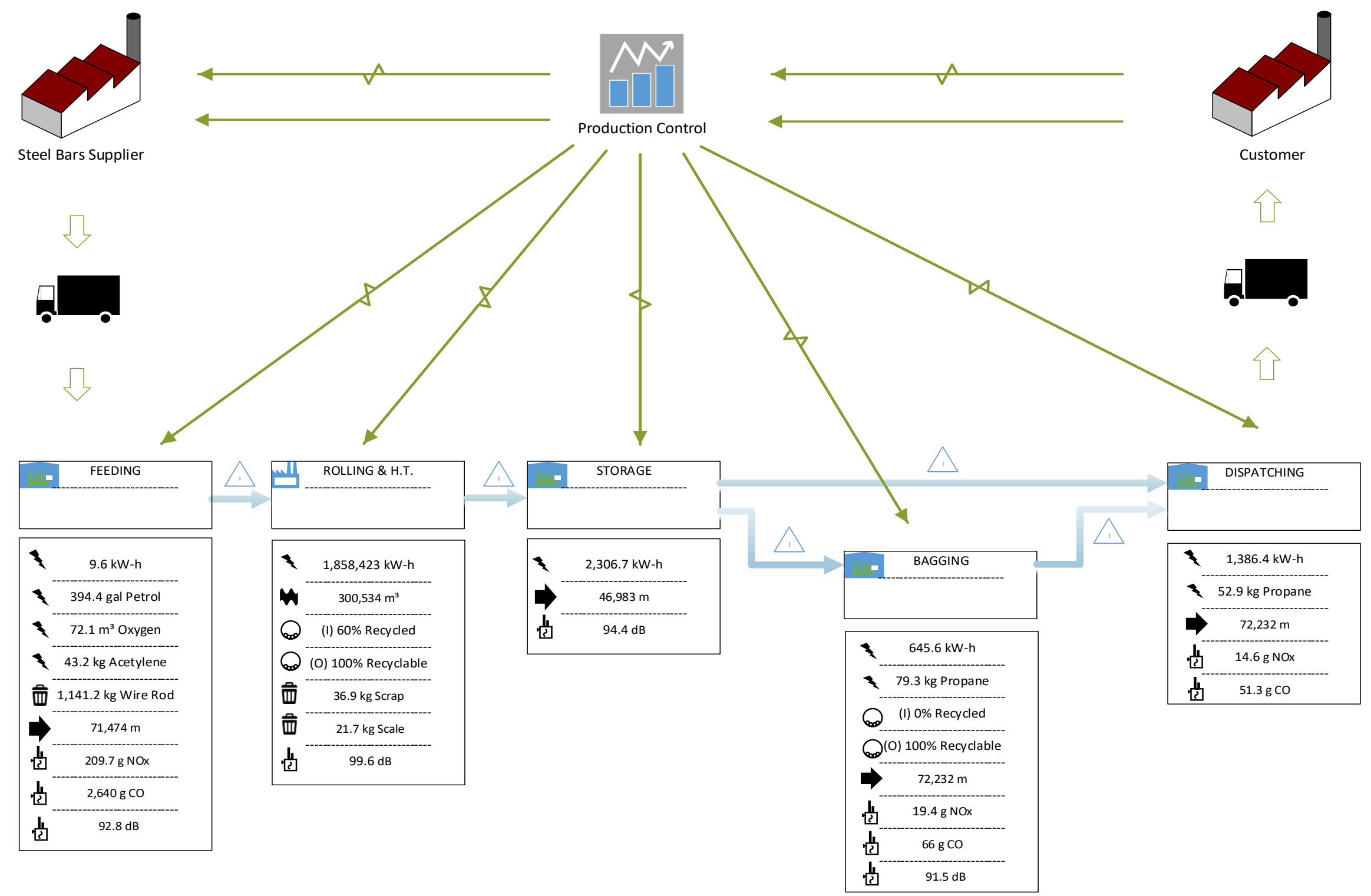

Figure 6. Current state E-VSM for the helical rolling process to manufacture grinding balls 
Table 1. Strategies for the elimination of green wastes in every stage of the helical rolling process

\begin{tabular}{|c|c|c|c|c|c|}
\hline $\begin{array}{r}\text { Process } \\
\text { Stages }\end{array}$ & $\begin{array}{c}\text { Feeding of } \\
\text { Raw Material }\end{array}$ & $\begin{array}{c}\text { Helical Rolling } \\
\text { and Heat } \\
\text { Treatment }\end{array}$ & Storage & Bagging & Dispatch \\
\hline Energy & \multicolumn{5}{|c|}{$\begin{array}{l}\text { - Energy conservation } \\
\text { - Adoption of energy efficient technologies } \\
\text { - Energy management } \\
\text { - Alternative sources of energy }\end{array}$} \\
\hline Water & & $\begin{array}{l}\text { - Water } \\
\text { conservation } \\
\text { - Water toxicity } \\
\text { minimisation } \\
\text { - Water reuse }\end{array}$ & & & \\
\hline$\overbrace{000}^{\text {Materials }}$ & & $\begin{array}{l}\text { - Pursuing } \\
100 \% \text { reuse } \\
\text { - Using } \\
\text { recycled input } \\
\text { and output } \\
\text { materials } \\
\text { - Minimising } \\
\text { materials } \\
\text { usage } \\
\text { - Elimination of } \\
\text { negative } \\
\text { impact } \\
\text { materials }\end{array}$ & & $\begin{array}{l}\text { - Pursuing } \\
100 \% \text { reuse } \\
\text { - Using } \\
\text { recycled input } \\
\text { and output } \\
\text { materials } \\
\text { - Minimising } \\
\text { materials } \\
\text { usage } \\
\text { - Elimination of } \\
\text { negative } \\
\text { impact } \\
\text { materials }\end{array}$ & \\
\hline $\begin{array}{c}\text { Garbage } \\
\text { 而 }\end{array}$ & $\begin{array}{l}\text { - Garbage } \\
\text { minimisation } \\
\text { - Reusing } \\
\text { garbage }\end{array}$ & $\begin{array}{l}\text { - Garbage } \\
\text { minimisation } \\
\text { - Reusing } \\
\text { garbage }\end{array}$ & & & \\
\hline Transportation & $\begin{array}{l}\text { - Minimisation } \\
\text { of transport } \\
\text { distances } \\
\text { - Alternative } \\
\text { eco-friendly } \\
\text { transportation }\end{array}$ & & $\begin{array}{l}\text { - Minimisation } \\
\text { of transport } \\
\text { distances } \\
\text { - Alternative } \\
\text { eco-friendly } \\
\text { transportation }\end{array}$ & $\begin{array}{l}\text { - Minimisation } \\
\text { of transport } \\
\text { distances } \\
\text { - Alternative } \\
\text { eco-friendly } \\
\text { transportation }\end{array}$ & $\begin{array}{l}\text { - Minimisation } \\
\text { of transport } \\
\text { distances } \\
\text { - Alternative } \\
\text { eco-friendly } \\
\text { transportation }\end{array}$ \\
\hline $\begin{array}{c}\text { Emission } \\
\text { 管 }\end{array}$ & $\begin{array}{l}\text { - Minimisation } \\
\text { of emissions } \\
\text { at the source }\end{array}$ & $\begin{array}{l}\text { - Minimisation } \\
\text { of emissions } \\
\text { at the source }\end{array}$ & & $\begin{array}{l}\text { - Minimisation } \\
\text { of emissions } \\
\text { at the source }\end{array}$ & $\begin{array}{l}\text { - Minimisation } \\
\text { of emissions } \\
\text { at the source }\end{array}$ \\
\hline
\end{tabular}

Negligible or no waste of that type in that stage of the process 
Table 2. Activities considered as part of the green wastes elimination/minimisation strategies

\begin{tabular}{|c|c|c|}
\hline Waste & Strategy & Actions/Alternatives \\
\hline \multirow{4}{*}{ Energy } & Energy conservation & $\begin{array}{l}\text { - Developing operational procedures to disconnect } \\
\text { devices when not required to work } \\
\text { - Utilising timers, sensor, etc. to automatically disconnect } \\
\text { or shut off devices when not in use } \\
\text { - Regulating the operation of devices according to the } \\
\text { intensity required for a specific labour }\end{array}$ \\
\hline & $\begin{array}{l}\text { Adoption of energy } \\
\text { efficient technologies }\end{array}$ & $\begin{array}{l}\text { - Acquire devices/equipment that provide the same } \\
\text { service but with minor energy consumption compared } \\
\text { with conventional devices/equipment }\end{array}$ \\
\hline & Energy management & $\begin{array}{l}\text { - Employing energy for a period of the day when the total } \\
\text { charge of devices is low. Barriers for this strategy } \\
\text { involve having to change working times or schedules } \\
\text { - Moving energy usage to off-peak times of the day }\end{array}$ \\
\hline & $\begin{array}{l}\text { Alternative sources of } \\
\text { energy }\end{array}$ & $\begin{array}{l}\text { - Adoption of generators of energy such as geothermal, } \\
\text { biomass, windmills, solar panels, and hydro turbines }\end{array}$ \\
\hline \multirow{3}{*}{ Water } & Water conservation & $\begin{array}{l}\text { - Implementing operational procedures, either automatic } \\
\text { or manual, to shut-off valves when machines are not } \\
\text { running or water is not required; putting in place strict } \\
\text { maintenance programs to eliminate or replace leaking } \\
\text { water dispensers; investigating whether the water is } \\
\text { supplied in the quantity needed and when required } \\
\text { - Using water-efficient technologies which perform the } \\
\text { same activity using less water through the employment } \\
\text { of more efficient water supplier devices }\end{array}$ \\
\hline & $\begin{array}{l}\text { Water toxicity } \\
\text { minimisation }\end{array}$ & $\begin{array}{l}\text { - Tackling first the water system that discharges the } \\
\text { highest content of toxins as well as the one that has the } \\
\text { highest impact in reducing fines when toxins are } \\
\text { removed } \\
\text { - Concentrating on the most harmful toxin and attempting } \\
\text { to eliminate the source } \\
\text { - If eliminating the source of the toxin is unviable, then } \\
\text { cleaning the toxicity of the water is an option }\end{array}$ \\
\hline & Water reuse & $\begin{array}{l}\text { - Classify the discharged water according to its grade of } \\
\text { impurity } \\
\text { - Clean Water - suitable for drinking } \\
\text { - Grey Water - not suitable for drinking but may be used } \\
\text { again } \\
\text { - Black Water - must be treated } \\
\text { - Decide where to employ the clean or grey water } \\
\text { identified }\end{array}$ \\
\hline \multirow{4}{*}{ Materials } & Pursuing $100 \%$ reuse & $\begin{array}{l}\text { - Design processes that allow a product to get back at the } \\
\text { end of its life }\end{array}$ \\
\hline & $\begin{array}{l}\text { Using recycled input and } \\
\text { output materials }\end{array}$ & $\begin{array}{l}\text { - Use input materials that have the higher recycled } \\
\text { contend as well as producing goods highly recyclables }\end{array}$ \\
\hline & $\begin{array}{l}\text { Minimising materials } \\
\text { usage }\end{array}$ & $\begin{array}{l}\text { - Implementing effective practice, e.g. lean, to minimise } \\
\text { the use of material }\end{array}$ \\
\hline & $\begin{array}{l}\text { Elimination of negative } \\
\text { impact materials }\end{array}$ & $\begin{array}{l}\text { - Eliminate materials categorised as having high impact } \\
\text { and risk on the environment and human health, i.e. those } \\
\text { categorised as red in an environmental impact } \\
\text { assessment }\end{array}$ \\
\hline $\begin{array}{l}\text { Garbage } \\
\text { Iㅣ }\end{array}$ & Garbage minimisation & $\begin{array}{l}\text { - Identify the origin of the garbage by identifying the } \\
\text { process or activity of the value stream where the garbage } \\
\text { was generated } \\
\text { - Analyse whether the amount of garbage may be reduced } \\
\text { or eliminated by changes in the process or activity that } \\
\text { generates it } \\
\text { - Analyse which material can be recycled or biodegraded }\end{array}$ \\
\hline
\end{tabular}




\begin{tabular}{|c|c|c|}
\hline & & $\begin{array}{l}\text { - Indicate the quantity of garbage that may be diverted } \\
\text { from going to landfill. It is the amount of materials being } \\
\text { recycled or biodegraded }\end{array}$ \\
\hline & Reusing garbage & $\begin{array}{l}\text { - Changing the size, shape, or characteristics of the } \\
\text { employed materials in order to make them recyclable, } \\
\text { reusable, or biodegradable }\end{array}$ \\
\hline \multirow{2}{*}{ Transportation } & $\begin{array}{l}\text { Minimisation of transport } \\
\text { distances }\end{array}$ & - Implementing cellular manufacturing practices \\
\hline & $\begin{array}{l}\text { Alternative eco-friendly } \\
\text { transportation }\end{array}$ & $\begin{array}{l}\text { - Implement, use or adapt eco-friendly fuels as well as } \\
\text { eco-friendly transportation ways }\end{array}$ \\
\hline Emission & $\begin{array}{l}\text { Minimisation of } \\
\text { emissions at the source }\end{array}$ & $\begin{array}{l}\text { - Identify the source of emission in the value stream and } \\
\text { note it in the waste elimination worksheet } \\
\text { - Investigate whether the process is working under } \\
\text { parameters of design } \\
\text { - Investigate whether process/activity can use less source } \\
\text { of emissions since any excess of material means excess } \\
\text { in cost and emissions } \\
\text { - Investigate whether the source of emission can be } \\
\text { replaced by a more eco-friendly substitute } \\
\text { - Examine options for altering, changing, or eliminating } \\
\text { the activity that is provoking the emission }\end{array}$ \\
\hline
\end{tabular}

\section{C9. Creating of the future state E-VSM}

The current state map provides a snapshot of the actual process operations and performance in an 'as-is' form (Saboo et al., 2014; Abdulmalek and Rajgopal, 2007). This helps in identifying wastes and hence prioritise and direct improvement efforts and resources more efficiently. However, the actual effectiveness of a VSM study lies not only on this characteristic but also on its capability to provide a vision and develop a value stream that depicts the ideal state of a process. In this context, the future state map enables businesses to look into the future by defining an ideal approach and performance to operate a process' value stream. In other words, a future VSM depicts the 'as-it-should-be' state (Barbereto Henrique et al., 2016). In the case of an E-VSM study, the future state map should portray the improvements that a process' value stream can attain by incorporating the green wastes elimination/minimisation strategies formulated, proposed and analysed in the previous step of the DMAIC-based approach to EVSM.

Figure 8 presents the future state map, i.e. ideal future state, of the helical rolling process by showing the potential improvements that this process may achieve after the implementation of the green wastes elimination/reduction strategies formulated and assessed in the previous step of the DMAIC-based approach to E-VSM. The process of creating the future E-VSM was the same as that followed during the creation of the current state map. In this case, the potential reduction of green wastes indicated by the analyses, see Figure 7, were transcribed to and illustrated in the future state map. These are illustrated in the future state map by noting the potential reduction that may be achieved in the header box of each process stage. Moreover, the adjusted values after subtracting the amount of potential waste reduction from the current values are noted in the data boxes to reflect the future state that is pretended. This is an important step in an E-VSM study as the future state map shows the environmental improvements that may be achieved by eliminating or reducing the green wastes identified in the current state map. 


\begin{tabular}{|c|c|c|c|c|c|c|}
\hline \multicolumn{7}{|c|}{ Garbage Waste Elimination Worksheet } \\
\hline Product: & \multicolumn{6}{|c|}{ Grinding Balls 2.1/2" } \\
\hline Production Line: & \multicolumn{6}{|c|}{ Helical Rolling $\mathbf{2}$} \\
\hline \multirow{2}{*}{\multicolumn{7}{|c|}{$\begin{array}{l}\text { 1. Feeding of Raw Material } \\
\text { Future State }\end{array}$}} \\
\hline & & & & & & \\
\hline \multicolumn{5}{|c|}{ Minimise } & \multicolumn{2}{|c|}{ Reuse } \\
\hline Material & Source of Garbage & Change & $\begin{array}{c}\text { Recycle / } \\
\text { Biodegrade }\end{array}$ & Savings & Solution & Savings \\
\hline Wire rod & $\begin{array}{l}\text { Bundle of raw } \\
\text { material }\end{array}$ & & $\begin{array}{l}\text { Already } 100 \% \\
\text { recyclable }\end{array}$ & & $\begin{array}{l}\text { Send it back to the } \\
\text { steel bar suppliers }\end{array}$ & $1,441.2 \mathrm{~kg}$ \\
\hline
\end{tabular}

a) Process stage: Feeding of Raw Material; Green waste: Garbage

\begin{tabular}{|c|c|c|c|c|}
\hline \multicolumn{5}{|c|}{ Transportation Waste Elimination Worksheet } \\
\hline Product: & \multicolumn{4}{|c|}{$\begin{array}{c}\text { Grinding Balls 2.1/2" } \\
\end{array}$} \\
\hline Production Line: & \multicolumn{4}{|c|}{ Helical Rolling 2} \\
\hline Step: & \multicolumn{4}{|c|}{ 3. Storage } \\
\hline \multicolumn{5}{|c|}{ Future State } \\
\hline \multicolumn{3}{|c|}{ Minimise } & \multicolumn{2}{|c|}{ Eco-Transortation } \\
\hline Item & Distance Solution & Savings & Solution & Savings \\
\hline $\begin{array}{c}\text { Grinding Balls } \\
\text { Boxes } 6 \mathrm{t}\end{array}$ & & & & \\
\hline
\end{tabular}

c) Process stage: Storage; Green waste: Transportation

\begin{tabular}{|c|c|c|c|c|c|c|c|c|}
\hline \multicolumn{9}{|c|}{ Materials Waste Elimination Worksheet } \\
\hline Product & \multicolumn{8}{|c|}{ Grinding Balls $2.1 / 2^{\prime \prime}$} \\
\hline Production Line: & \multicolumn{8}{|c|}{ Helical Rolling 2} \\
\hline Step & \multicolumn{8}{|c|}{ 4. Bagging } \\
\hline \multicolumn{9}{|c|}{ Future State } \\
\hline \multicolumn{9}{|c|}{ Minimise } \\
\hline Item \& Qty & \multicolumn{2}{|c|}{ Harmful Materials } & \begin{tabular}{|c|}
$\begin{array}{c}\text { Proposal } \\
\text { for } \\
\text { Minimise }\end{array}$ \\
\end{tabular} & Savings & $\begin{array}{c}100 \% \\
\text { Technical \& } \\
\text { Biological } \\
\text { Nutrient }\end{array}$ & $\begin{array}{c}\text { 100\% Technical } \\
\text { \& Biological } \\
\text { Nutrient }\end{array}$ & Reuse & Savings \\
\hline $\begin{array}{l}\text { Polypropylene } \\
\text { Bag }\end{array}$ & Rated yellow & $\begin{array}{c}\text { Do not requires } \\
\text { change }\end{array}$ & & & $0 \%$ & Already $100 \%$ & & \\
\hline
\end{tabular}

d) Process stage: Bagging; Green waste: Materials

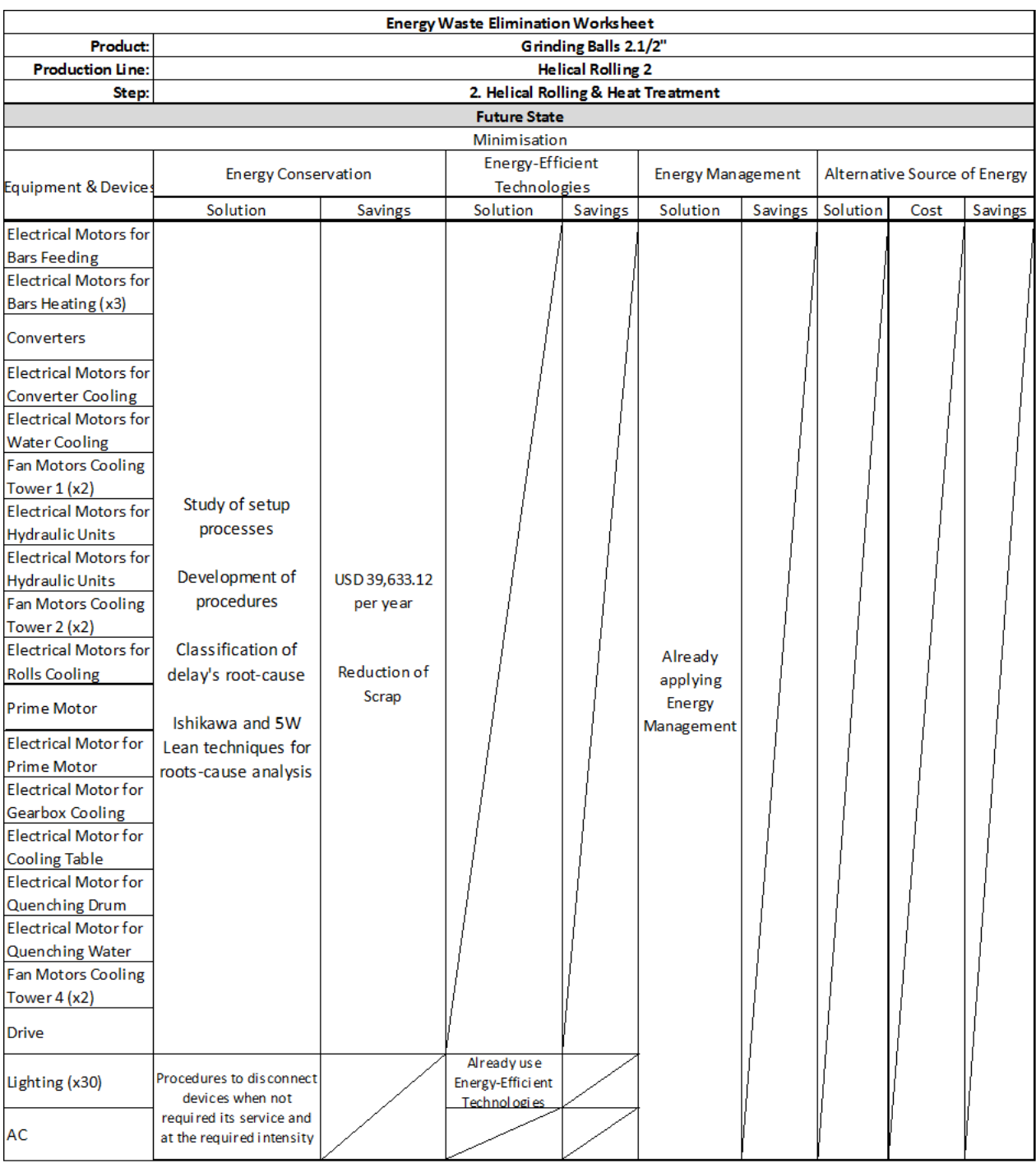

b) Process stage: Helical Rolling and Heat Treatment; Green waste: Energy

Figure 7. Evidence of strategies' assessment for green wastes in some process stages 


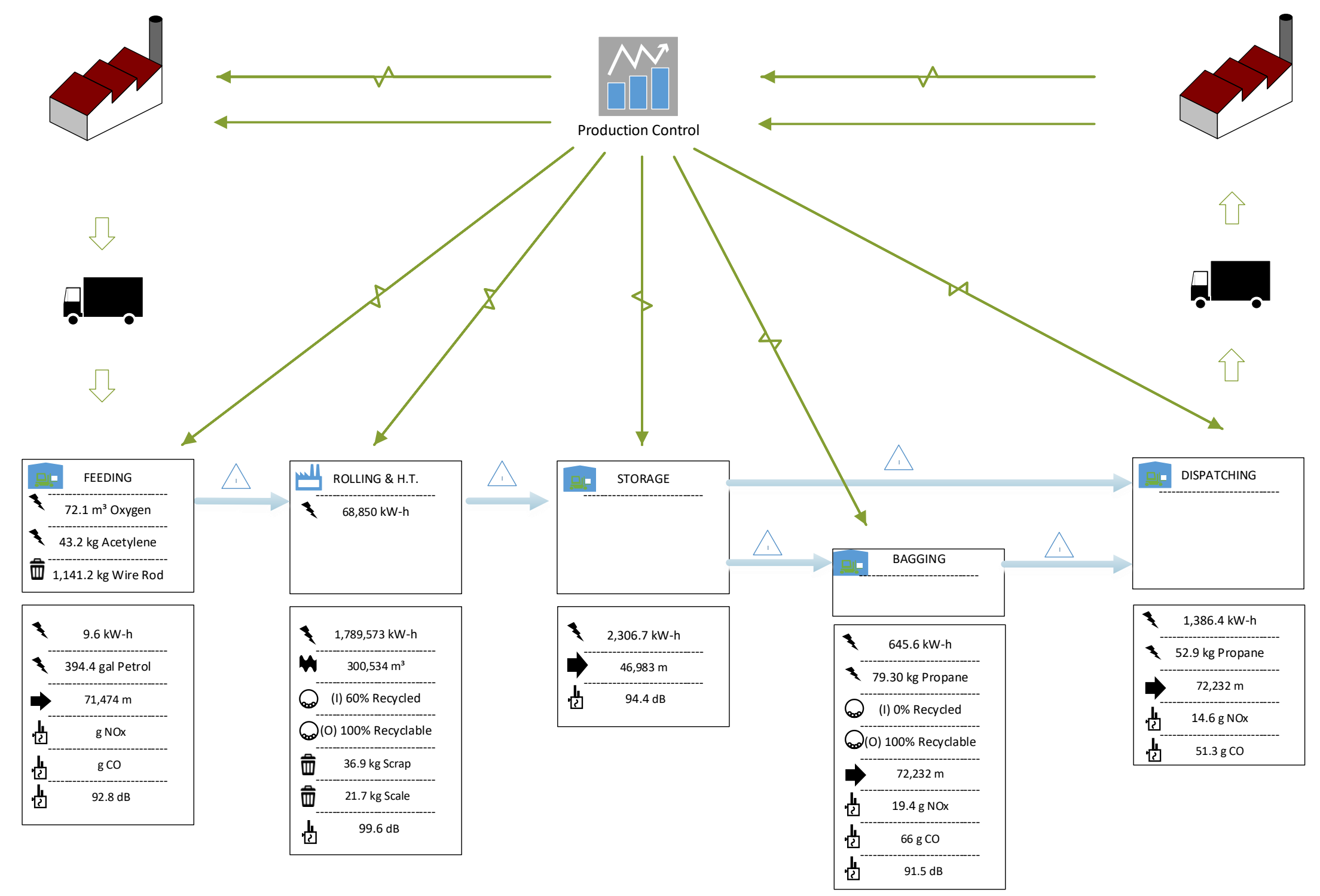

Figure 8. Future state E-VSM for the helical rolling process to manufacture grinding balls 


\subsection{Act stage}

\section{A10. Formulation of a plan for the implementation of the future E-VSM}

Once that the future state map has been created, the following step in the proposed method to E-VSM consists in the origination of a plan to implement the strategies previously conceived to eliminate/minimise the green wastes, and in this way 'transform' the studied value stream into its desired future state. In this context, the establishment of objectives and goals form the basis of a plan as these provide the rationale to go forward and a clear direction as to what needs to be done and achieved (Chiarini, 2013). Objectives and goals will also serve as a basis for monitoring and controlling the progress and success of the E-VSM implementation. This aspect is an essential element in the deployment of lean practices as Kumar and Phrommathed (2006) comment that absence of monitoring and controlling on the implementation of lean results in failures towards a lean transformation. Thus, to develop a plan for the implementation of the future state E-VSM, individual objectives and goals were set for the elimination/minimisation of green wastes. Additionally, as suggested by Wilson (2010), key performance indicators (KPIs) were also established for each individual objective and goal, with the premise that they should be easy to understand and compare with benchmarks or standards. This was essential as KPIs enable the measurement and tracking of the implementation progress of an E-VSM future state map. An objective and goal-based plan, also including KPIs, was formulated for every stage of the helical rolling process. Table 3 shows an example of a future state E-VSM implementation plan formulated, particularly, for the helical rolling and heat treatment stage of the helical rolling process.

Table 3. Objective and goal-based implementation plan for future state E-VSM - helical rolling and heat treatment stage

\begin{tabular}{|c|c|c|c|}
\hline Process Stage & Objective & Measurable Goal & KPI \\
\hline \multirow{9}{*}{$\begin{array}{l}\text { Helical Rolling and Heat } \\
\text { Treatment }\end{array}$} & $\begin{array}{l}\text { To have all kinds of set } \\
\text { up delays measured }\end{array}$ & $\begin{array}{c}\text { Every cause of delay } \\
\text { categorised and } \\
\text { measured } \\
\end{array}$ & Delay time [hours] \\
\hline & $\begin{array}{l}\text { Stabilisation of set up } \\
\text { times }\end{array}$ & 5.9 hours & Set up time [hours] \\
\hline & $\begin{array}{l}\text { Reduction of energy } \\
\text { consumption }\end{array}$ & $3.7 \%$ & $\begin{array}{l}\text { Energy consumption } \\
\text { KW-h/month }\end{array}$ \\
\hline & $\begin{array}{l}\text { Reduction of water } \\
\text { consumption at cooling } \\
\text { towers by employing } \\
\text { alterative water valves }\end{array}$ & $5.0 \%$ & $\begin{array}{l}\text { Water consumption } \\
{\left[\mathrm{m}^{3} / \mathrm{month}\right]}\end{array}$ \\
\hline & $\begin{array}{l}\text { To have specific spots to } \\
\text { measure volume } \\
\text { discharged and toxicity } \\
\text { for each water system }\end{array}$ & 4 water systems & $\begin{array}{l}\text { Water discharged } \\
{\left[\mathrm{m}^{3} / \mathrm{moth}\right] ; \text { Toxicity rate }} \\
{\left[\mathrm{gr} / \mathrm{m}^{3}\right]}\end{array}$ \\
\hline & $\begin{array}{l}100 \% \text { of water use } \\
\text { discharged from } \\
\text { converters cooling } \\
\text { system }\end{array}$ & $100 \%$ & $\begin{array}{l}\text { Volme of reused water } \\
{\left[\mathrm{m}^{3}\right]}\end{array}$ \\
\hline & $\begin{array}{l}\text { To have all kind of scrap } \\
\text { measured }\end{array}$ & $\begin{array}{c}\text { Every cause of scrap } \\
\text { generation categorised } \\
\text { and measured }\end{array}$ & $\begin{array}{l}\text { Scrap volume } \\
{[\mathrm{kg} / \mathrm{month}]}\end{array}$ \\
\hline & $\begin{array}{l}\text { Reduction of scrap } \\
\text { generation }\end{array}$ & $50 \%$ & $\begin{array}{l}\text { Total Scrap volume } \\
\text { [kg/month] }\end{array}$ \\
\hline & $\begin{array}{l}\text { To have the amount of } \\
\text { garbage, i.e. grease, } \\
\text { hydraulic oil and oil rags } \\
\text { quantified }\end{array}$ & $\begin{array}{l}100 \% \text { of disposed } \\
\text { grease, hydraulic oil and } \\
\text { oil rags quantified }\end{array}$ & $\begin{array}{l}\text { Grease }[\mathrm{kg} / \text { month }] ; \text { Oil } \\
\text { volume }\left[\mathrm{m}^{3} / \text { month }\right]\end{array}$ \\
\hline
\end{tabular}




\begin{tabular}{|l|l|c|l|}
\hline & Reduce the use of grease & $25 \%$ & $\begin{array}{l}\text { Grease volume } \\
{[\mathrm{kg} / \mathrm{month}]}\end{array}$ \\
\cline { 2 - 4 } & Reuse of hydraulic oil & $100 \%$ & $\begin{array}{l}\text { Hydraulic Oil Volume } \\
{\left[\mathrm{m}^{3} / \mathrm{month}\right]}\end{array}$ \\
\cline { 2 - 5 } & Eliminate oil leaking & none & Number of leaking spots \\
\hline
\end{tabular}

\section{A.11 Implementation of plan to achieve the future state E-VSM}

The implementation of the plan formulated in the previous stage is the last step in the proposed approach to E-VSM. Thus, this step corresponds to the execution phase that will deliver and enable the 'transformation' from the current to the future state E-VSM of the studied value stream. In practice, constraints in resources such as investment, time, personnel, etc. may make the implementation of all the strategies devised to eliminate the green wastes impossible to deploy at the same time. This is because according to Marriot et al. (2013), organisations can only assign limited resources to the improvement of their processes, services and/or products. For this reason, it might be necessary to prioritise the implementation of those strategies based on those that will provide optimum solutions with high benefits and relatively low implementation costs (Garza-Reyes et al. 2016b).

One that some specific strategies have been prioritised, if this is the case, an action plan must be created by the team, or person, designated to be in charge of implementing the green wastes elimination/minimisation strategies. The action plan may include the assignment of resources to certain implementation activities and an implementation evaluation. The implementation evaluation is a process for reassessing the empirical implementation of the proposed strategies (Mostafa et al., 2013). The evaluation can be done by regularly comparing the objectives and goals achieved against the progress made at specific points in time during the implementation timeframe.

According to Rother and Shook (2003), the best way to start with the implementation of a future state VSM is from the peacemaker process (Qassim et al., 2015). This is the closest process to the customer (Saboo et al., 2014), which acts as an internal customer, then going upstream through the other processes of the value stream. Under this condition, the peacemaker process for this study was considered to be the dispatching stage, see Figure 2. For this reason, the implementation of the plan to achieve the future state E-VSM was initiated in this stage of the helical rolling process, and later moved upstream through bagging, helical rolling \& heat treatment, to complete it in the feeding of raw materials process stage. Figure 9 shows an example of a future state E-VSM implementation plan. A suggested by Rother and Shook (2003), the implementation plan is presented in the form of a Gantt chart.

The full implementation of the plan and hence of the prioritised green wastes elimination/minimisation strategies is currently under way in the case organisation; thus, it is still not possible to present the final results of this E-VSM study and determine its success. However, extensive empirical evidence (e.g. Prashar, 2017; Zhang et al., 2015; Qassim et al., 2015; Vinodh et al., 2014; Krueger et al., 2014; Nakashima et al., 2006) suggests that a systematic approach with logically and well-defined sequenced transitional stages, such as those facilitated by the proposed PDCA-based approach to E-VSM, will provide a more effective and efficient approach to operations improvement (Garza-Reyes et al., 2016b). Therefore, it is possible to predict that if the implementation plan is successfully deployed, the case organisation will be able to reduce some of the environmental wastes as suggested by the comparison between the current and future state E-VSMs. 


\section{Concluding Remarks, Limitations and Future Research}

This paper presents a novel PDCA-based approach to systematically conduct an E-VSM analysis. The research is therefore among the very limited number of studies that have considered the application of the highly used VSM tool to address the environmental challenges currently faced by organisations. For this reason, this study advances our knowledge in the field of green lean and fills a research gap, as previously highlighted in Section 1, by:

- Providing further evidence of the application of lean methods and tools, specifically VSM, and validating their effectiveness to address the critical environmental issues currently raised by unsustainable manufacturing and production operations;

- Proposing a logically and well-defined sequenced approach, based on the Deming's PDCA method, for companies to systematically conduct E-VSM studies;

- Presenting the application of the proposed approach not only to validate it but also to serve as a guiding reference for operations managers who may wish to undertake similar improvement projects; and (hopefully)

- Inspiring researchers and practitioners to conduct further studies on green lean, and specifically, the application of VSM as a tool to enhance environmental sustainability in order to broaden the study of this under-researched field.

These contributions are beneficial for managers, and their companies, who aim to improve the green performance of their operations by using lean principles, tools and techniques. Due to the extensive applicability of VSM and lean in other sectors where they have been applied, e.g. healthcare (e.g. Teichgräber and de Bucourt, 2012), services (e.g. Barber and Tietje, 2008), logistics and transport (Garza-Reyes et al., 2016a; Villarreal et al. 2016), etc., these are also likely to benefit from the method proposed in this paper. These industrial sectors are under increasing pressure to be more environmentally sustainable and the effective implementation of E-VSM can provide them with an opportunity to achieve this endeavour.

Within the context of the case organisation, the results obtained from the implementation of the proposed DMAIC-based approach to E-VSM suggest that it can be an effective alternative to improve the green performance of operations. This corroborates the positive results also obtained by Wills (2009), Torres and Gati (2009), Lai et al. (2008), Kurdve et al. (2011), Braås. Folinas et al. (2014), Brown et al. (2014), Faulkner and Badurdeen (2014), Garza-Reyes et al. (2016a), Deif (2011), Kuriger et al. (2011), Dadashzadeh and Wharton (2012), Simons and Mason (2002), Fearne and Norton (2009) and Paju et al. (2010) when using VSM to enhance environmental and sustainability performance.

In this particular case, it is suggested that if the case company effectively implements the action plan to deploy the green waste elimination/minimisation strategies, it will be able to reduce the consumption of energy and the production of garbage in the feeding and helical rolling and heat treatment stages of its manufacturing process that produces grinding balls. This provides an important practical contribution for organisations that can use the proposed PDCAbased approach as a reference to conduct similar improvement projects. We hope that our proposed approach would also encourage industrialists, and thus their companies, and assist them in achieving more environmentally sustainable operations. To advance this area further, research is needed to provide an understanding of the benefits, challenges and define the critical success factors for the effective deployment of E-VSM studies. On the other hand, the PDCAbased approach to E-VSM proposed in this paper was specifically applied within the context of the manufacturing operations of only one organisation. Therefore, further research can focus on validating this approach in other companies not only to improve manufacturing operations but also other type of operations such as logistics and transport, healthcare, services, among 
others. This research stream is one of the main future research directions proposed from this work.

\section{References}

Abdulmalek, F.A., Rajgopal, J. (2007), "Analyzing the benefits of lean manufacturing and value stream mapping via simulation: A process sector case study", International Journal of Production Economics, 107(1), 223-236.

Barber, S., Tietje, B.C. (2008), "A research agenda for Value Stream Mapping the sales process”, Journal of Personal Selling \& Sales Management, 28(2), 155-165.

Barberato Henrique, D., Freitas Rentes, A., Godinho Filho, M., Francisco Esposposto, K. (2016), "A new value stream mapping approach for healthcare environments", Production Planning \& Control, 27(1), 24-48.

Belekoukias, I., Garza-Reyes, J.A., Kumar, V. (2014), "The impact of lean methods and tools on the operational performance of manufacturing organisations", International Journal of Production Research, 52(18), 5346-5366.

Bergmiller, G.G., McCright, P.R. (2009), “Are lean and green programs synergistic?" Industrial Engineering Research Conference, Miami, FL, May 30-June 3.

Brown, A., Amundson, J., Badurdeen, F. (2014), "Sustainable value stream mapping (SusVSM) in different manufacturing system configurations: application case", Journal of Cleaner Production, 85, 164-179.

Cherrafi, A., El Fezazi, S., Govindan, K., Garza-Reyes, J.A., Mokhlis, A., Benhida, K. (2017a), "A framework for the integration of Green and Lean Six Sigma for superior sustainability performance", International Journal of Production Research, 55(15), 4481-4515.

Cherrafi, A., Elfezazi, S., Garza-Reyes, J.A., Benhida, K., Mokhlis, A. (2017b), "Barriers in Green Lean implementation: a combined Systematic Literature Review and Interpretive Structural Modelling approach", Production Planning \& Control: The Management of Operations, DOI: http://dx.doi.org/10.1080/09537287.2017.1324184 - in press.

Chiarini, A. 2013, Lean organisation: from the tools of the Toyota production system to lean office, $1^{\text {st }}$ ed, Springer, Milan.

Chiarini, A. (2014), "Sustainable manufacturing-greening processes using specific lean production tools: an empirical observation from European motorcycle component manufacturers", Journal of Cleaner Production, 85, 226-233.

Coughlan, P., Coghlan, D. (2002), “Action research for operations management”, International Journal of Operations and Production Management 22(2): 220-240.

Dadashzadeh, M., Wharton, T.J. (2012), "A value stream approach for greening the IT department", International Journal of Management and Information Systems, 16(2), $125-136$.

Deif, A.M. (2011), “A system model for green manufacturing”, Journal of Cleaner Production, $19,1553-1559$.

Dickson, E., Singh, S., Cheung, D., Wyatt, C., Nugent, A. (2009), "Application of lean manufacturing techniques in the emergency department", The Journal of Emergency Medicine, 37(2), 177-182.

Dües, C.M., Tan, K.H., Lim, M. (2013), "Green as the new lean: how to use lean practices as a catalyst to greening your supply chain”, Journal of Cleaner Production, 40, 93-100. 
Faulkner, F., Badurdeen, F. (2014), "Sustainable Value Stream Mapping (Sus-VSM): methodology to visualize and assess manufacturing sustainability performance", Journal of Cleaner Production, 85, 8-18.

Fearne, A., Norton, A. (2009), "Sustainable value stream mapping in the food industry", In: Waldron, K. (Ed.), Handbook of Waste Management and Co-product Recovery in Food Processing, Woodhead Publishing, Cambridge.

Folinas, D., Aidonis, D., Malindretos, G., Voulgarakis, N., Triantafillou, D. (2014), "Greening the agrifood supply chain with lean thinking practices", International Journal of Agricultural Resources, Governance and Ecology, 10(2), 129-145.

Forno, A., Pereira, F., Forcellini, F., Kipper, L. (2014), "Value Stream Mapping: a study about the problems and challenges found in the literature from the past 15 years about application of lean tools", The International Journal of Advanced Manufacturing Technology, 72(5), 779-790.

Forrester, P.L., Shimizu, U.K., Soriano-Meier, H., Garza-Reyes, J.A., Cruz Basso, L.F. (2010), "Lean Production, Market Share and Value Creation in the Agricultural Machinery Sector in Brazil", Journal of Manufacturing Technology Management, 21(7), 853-871.

Franchetti, M., Bedal, K., Ulloa, J., Grodek, S. (2009), "Lean and green: industrial engineering methods are natural stepping stones to green engineering", Industrial Engineer, 41(9), 24-29.

Furterer, S.L. (2009), Lean Six Sigma in Service, CRC Press, Boca Raton, FL.

Garza-Reyes, J.A., Winck Jacques, G., Lim, M.K., Kumar, V., Rocha-Lona, L. (2014), "Lean and green - synergies, differences, limitations, and the need for Six Sigma", in $B$. Grabot et al. (Eds.): International Conference on Advances in Production Management Systems (APMS) 2014, Part II, IFIP AICT 439, Ajaccio, France, 20-24 September, Springer.

Garza-Reyes, J.A. (2015a), "Lean and Green - A systematic review of the state of the art literature", Journal of Cleaner Production, 102, 18-29.

Garza Reyes, J.A. (2015b), "Green Lean and the need for Six Sigma”, International Journal of Lean Six Sigma, 6(3), 226-248.

Garza-Reyes, J.A., Villarreal, B., Kumar, V., Molina Ruiz, P. (2016a), "Lean and Green in the Transport and Logistics Sector - A Case Study of Simultaneous Deployment", Production Planning \& Control: The Management of Operations, 27(15), 1221-1232.

Garza-Reyes, J.A., Al-Balushi, M., Antony, J., Kumar, V. (2016b), “A Lean Six Sigma framework for the reduction of ship loading commercial time in the Iron Ore Pelletising industry", Production Planning \& Control: The Management of Operations, Vol. 27(13), 1092-1111.

Gutierrez, D.M., Scavarda, L.F., Fiorencio, L., Martins, R.A., (2015), "Evolution of the performance measurement system in the logistics department of a broadcasting company: an action research", International Journal of Production Economics, 160: 112.

Hamad, W., Crowe, J., Arisha, A. (2012), Towards leaner healthcare facility: Application of simulation modelling and value stream mapping, Dublin Institute of Technology, Dublin.

Hines, P., Holweg, M., Rich, N., (2004), "Learning to Evolve." International Journal of Operations and Production Management, 24(10), 994-1011. 
Jeyaraj, K., Muralidharan, C., Mahalingam, R., Deshmukh, S. (2013), “Applying Value Stream Mapping technique for production improvement in a manufacturing company: A case study", Journal of The Institution of Engineers (India): Series C, 94(1), 43-52.

Kumar, S., Phrommathed, P. (2006), "Improving a manufacturing process by mapping and simulation of critical operations", Journal of Manufacturing Technology Management, 17(1), 104-132.

Kurdve, M., Hanarp, P., Chen, X., Qiu, X., Yan, Z., John, S., Jonas, L. (2011), "Use of environmental value stream mapping and environmental loss analysis in lean manufacturing work at Volvo", In: Proceedings of the 4th Swedish Production Symposium (SPS11), Lund, Sweden, May 3rd-5th.

Kuriger, G., Huang, Y., Chen, F. (2011), “A lean sustainable production assessment tool”, In: Proceedings of the 44th CIRP Conference on Manufacturing Systems, May 31-June 3, Madison, Wisconsin.

Krueger, D.C., Parast, M.M., Adam, S. (2014), "Six sigma implementation: a qualitative case study using grounded theory", Production, Planning \& Control 25(10), 873-889.

Lai, J., Harjati, A., McGinnis, L., Zhou, C., Guldberg, T. (2008), "An economic and environmental framework for analyzing globally sourced auto parts packaging system", Journal of Cleaner Production, 16, 1632-1646.

Marriott, B., Garza-Reyes, J.A., Soriano-Meier, H., Antony, J. (2013), "An integrated methodology to prioritise improvement initiatives in low volume-high integrity product manufacturing organisations", Journal of Manufacturing Technology Management, 24(2), 197-217.

Mostafa, S., Dumrak, J., Soltan, H. (2013), “A framework for lean manufacturing implementation", Production \& Manufacturing Research, 1(1), 4464.

Nakashima, N., Nose, T., Kuriyama, S. (2006), "A new approach to environmentalperformance evaluation", International Journal of Production Research, 44(18-19), 4137-4143.

Nash, M.A., Poling, S.R. (2011), Mapping the total value stream: a comprehensive guide for production and transactional processes, Productivity Press, CRC Press, Taylor \& Francis, Boca Raton, FL.

Pampanelli, A.B., Found, P., Bernardes, A.M. (2014), "A Lean \& Green Model for a production cell", Journal of Cleaner Production, 85-19-30.

Paju, M., Heilala, J., Hentual, M., Heikkila, A., Johansson, B., Leong, S., Lyons, S. (2010), "Framework and indicators for a sustainable manufacturing mapping methodology", In: Proceedings of the 2010 Winter Simulations Conference, December 5-8, Baltimore, Maryland, 3411-3422.

Prashar, A. (2017), “Adopting PDCA (Plan-Do-Check-Act) cycle for energy optimization in energy-intensive SMEs" Journal of Cleaner Production, 145, 277-293.

Qassim, O., Garza-Reyes, J.A., Lim, M.K., Kumar, V. (2015), “Integrating Value Stream Mapping and PDCA to improve the operations of a pharmaceutical organisation in Pakistan", Proceedings of the $23^{\text {rd }}$ International Conference for Production Research (ICPR), Manila, Philippines, 2-5 August.

Rocha-Lona, L., Garza-Reyes J.A., Kumar, V. (2013), Building quality management systems: selecting the right methods and tools, Productivity Press, CRC Press, Taylor \& Francis, Boca Raton, FL. 
Rother, M., Shook, J. (2003), Learning to see: value stream mapping to create value and eliminate muda, Version 1.3, Lean Enterprise Institute, Cambridge, MA.

Saboo, A., Garza-Reyes, J.A., Er, A., Kumar, V. (2014), "A VSM improvement-based approach for lean operations in an Indian manufacturing SME", International Journal of Lean Enterprise Research, 1(1), 41-58.

Shadish, W.R., Cook, T.D., Campbell, D.T. (2002), Experimental and Quasi-experimental Designs for Generalized Causal Inference, Houghton Mifflin, Boston, MA.

Simons, D., Mason, R. (2002), "Environmental and transport supply chain evaluation with sustainable value stream mapping", In: 7th Logistics Research Network Conference, Birmingham, UK.

Teichgräber, U.K., de Bucourt, M. (2012), “Applying Value Stream Mapping Techniques to eliminate non-value-added waste for the procurement of endovascular stents", European Journal of Radiology, 81(1), e47-e52.

Tomelero, R., Ferreira, J.C., Kumar, V., Garza-Reyes, J.A. (2017), "Lean environmental benchmarking for the management of cutting tools", International Journal of Production Research, 55(3), 3788-3807.

Torres, A., Gati, A., (2009), "Environmental value stream mapping (EVSM) as sustainability management tool", In: Proceedings of Portland International Center for Management of Engineering and Technology Conference, August 2-6, Portland, Oregon, 1689-1698.

Villarreal, B., Garza-Reyes, J.A., Kumar, V. (2016), "Lean road transportation - a systematic method for the improvement of road transport operations", Production Planning \& Control, 27(1), 865-877.

Vinodh, S., Kumar, S.V., Vimal, K.E.K. (2014), "Implementing lean sigma in an Indian rotary switches manufacturing organisation", Production, Planning \& Control 25 (4), 288302.

Wills, B. (2009), Green intentions: creating a green value stream to compete and win, Taylor $\&$ Francis, New York.

Wilson, L. (2010), How to implement lean manufacturing, McGraw-Hill, NY.

Womack, J.P. (2006), "Value stream mapping", Manufacturing Engineering, 136(5), 145-156.

Zhang, M., Wang, W., Goh, T.N., He, T. (2015), “Comprehensive six sigma application: a case study", Production, Planning \& Control 26(3), 219-234. 